\title{
The principle of objective truth in law
}

\author{
Natalia Embulaeva ${ }^{1, *}$, and Lyubov Ilnickaya ${ }^{1}$ \\ ${ }^{1}$ Kuban State Agrarian University named after I. T. Trubilin, 350044, 13 Kalinin str., Krasnodar, \\ Russia
}

\begin{abstract}
The relevance of the study of the problems of truth in law is conditioned by the essential nature of man and his purposeful activity, including the sphere of legal regulation of social relations. At the present stage, the issue of securing the principle of truth in the norms of Russian law is not unambiguously resolved. In this regard, it seems relevant to investigate the issues of the legalization of truth and the mechanisms for its achievement in the conditions of application of measures of legal responsibility. The paper is devoted to the study of philosophical foundations of truth in law, the analysis of practical significance of obtaining truth in the procedural branches of law on the basis of analysis of the norms of the procedural legislation of the Russian Federation. Formallegal and comparative-legal methods are used for a comprehensive analysis of procedural legislation and the implementation of the principle of objective truth in the legislation. With the use of the dialectical method, epistemological grounds and their significance for the implementation of law enforcement activities are revealed. The article reflects the views of researchers on the content of truth and the realization of the principle of objective truth in law. The conclusion is made that it is necessary to interpret the principle of objective truth as universal one, which must permeate not only the sphere of law enforcement, but also the formation of laws. A proposal is formulated on the need to separate and normatively fix the principle of objective truth in the procedural branches of law as an independent principle. Law enforcement agencies should strive achieving objective truth in the cases in question.
\end{abstract}

\section{Introduction}

The questions of the truth of knowledge are rooted in philosophy and the theory of cognition. The main points of establishing truth in law is to understand, first, the ways and means of obtaining truth, and, second, the forms of its existence and implementation. Law as a means and mechanism for the regulation of social relations is objective in nature and must have a true knowledge about the content of social and state interrelations as its basis. The principle of objective truth must lie in the foundation of the construction of the entire legal system and the system of law, in particular.

The definition of the content of the principle of objective truth directly depends on its interpretation, on the solution of the question of the attainability of truth. Truth can be

* Corresponding author: nembulaeva@ mail.ru 
considered in various aspects. Truth as an experienced reality, truth as a property of selfconsistency of knowledge, truth as a utility of knowledge and its effectiveness [1], and truth as an agreement [2]. Within the framework of classical understanding, truth is nothing but a correspondence to reality. This approach is supported by many authors, beginning from Aristotle [3] and ending with modern philosophers. One should agree with the point of view according to which the classical interpretation of truth should be supplemented by such parameters as objectivity and evidence [4].

Truth must objectively reflect the reality that exists independently of the person's consciousness. At the same time, since man, as a subject of cognition, brings subjectivity into knowledge, truth can be regarded as a spiritual reality. Moreover, since socio-historical practice is the main criterion of truth [5], truth must be practically reproducible and provable. In the case of law and the legal system, the system of law and its branches, it is also true that truth can be regarded as a process, as a dynamic reality. Thus, truth combines the objective and subjective components and can be considered both in static and in dynamics.

Describing truth, it should be said about its over-historical nature and concreteness. Following the interpretation of truth as a dynamic process, it is necessary to recognize the validity of the indication of the time of the object and the subject as applied to a particular truth. Otherwise, truth will lose its objective character.

Objective truth in law involves several aspects of consideration. First, the ontological aspect consists in the being of truth as an essential characteristic of man, who seeks truth. A person wants to know truth for an adequate orientation in reality. Lying for salvation distorts reality.

Secondly, that is essential for our research, is the axiological aspect of the study of truth, which consists of the moral component of truth, determining its value content and influence on the practical activity of legal subjects. Explanatory dictionary of V. Dal defines truth precisely from this point of view as "the opposite to lies; all that is true, exactly, just; all that is truth. Now the word is equivalent to correctness, although it will be more accurate to understand by the word "correctness" truthfulness, justice, judgment, and rightness. Truth refers [more] to mind and reason, but good or goodness refer to love, disposition and will" [6]. Thus, it is objective truth that must underlie the implementation of justice as a special type of state activity.

The third aspect of the category of truth is praxeological one. It demonstrates the practical significance of true knowledge, the connection of truth with practice, its usefulness, because truth offers opportunities for carrying out law enforcement activities. As the Russian philosopher B.I. Lipsky correctly notes, practice proves truth only in order for this certified truth to serve further development of practice. Thereby truth is regarded as "the content of human consciousness, corresponding to objective reality and acting as the theoretical basis for its transformation to achieve a subjective goal" [7]. This definition of truth is suitable for a meaningful interpretation of the principle of objective truth within the procedural branches of law.

Since objective truth is regarded as a process, it must be aimed at achieving the greatest completeness of the reflection of the object of investigation, as well as overcoming delusions.

The unexpected aspect of truth is found in the concept of Michel Foucault, where he draws attention to "the games of truth", in which the relations of power play a special role [8]. According to his idea, with regard to legal relations, a lawyer who received appropriate professional training should be recognized as the subject of knowledge of truth. Only he can establish truth in the case, relying on acceptable, from the legal point of view, evidence. Accordingly, having true knowledge, the law enforcers will have power over all the others. 
The offender, his motives, goals, attitude to the act and its consequences will be an object of knowledge. Thus, truth will be mediated by power relations in the law.

In jurisprudence, the concepts of truth are refracted differently than in the natural sciences. Here the leading role is played by the value bases of the existence of man and society. Determining truth of the knowledge obtained, it is necessary that they correspond to the mentality. According to V.A. Kanke, practical sciences (to which belongs jurisprudence) "are called upon to ensure the most effective actions of people connected with the implementation of their pragmatic values. The proposals of pragmatic sciences are true providing they ensure the effectiveness of actions" [9]. In the legal sphere, we can talk about establishing all elements of the offense and determine the measure of legal responsibility, but it is more important to establish whether the liability is identified fairly.

The principles of law are interpreted as fundamental ideas, the initial principles underlying the legal regulation of social relations. The principle of objective truth should be attributed to the universal principles of law that take place and act not only in various branches of law within the national legal system, but also in the legal systems of other states, in the practice of international law.

The need for obtaining truth in the criminal process was already discussed in the Criminal Procedure Code of 1864, for example, when it came to questioning an accused, during which other legal means should be used to reveal the truth if the accused refused to answer the questions of the investigating judge. At the same time, a number of guarantees of the rights of the accused in the conduct of investigative actions were established [10].

Traditionally, the principle of objective truth is considered in relation to civil and criminal justice and is a matter of dispute among scientific and practical workers. At the present stage, this principle is not normatively fixed in any of the procedural codes of Russia, but this does not mean that the truth issues are not analyzed in civil or criminal cases. This is especially true for the limits of establishing the circumstances of the case by the bodies that carry out the proceedings: are they obliged to establish their correspondence to what actually happened?

The construction of modern judicial proceedings on the basis of the principle of adversarial means the separation of the procedural functions of the court and the parties. Parties compete with each other through the implementation of procedural actions aimed at justifying their claims and objections. In the trial, the parties have equal opportunities to present evidence and bring complaints and petitions. The court is required to ensure compliance with the established procedure for the consideration of the case, and, if necessary, to assist the parties in the exercise of their rights and obligations. The court is not entitled to substitute the parties for the performance of their procedural functions.

Courts make decisions on the basis of evidence submitted by the parties in support of their claims and objections. However, V.V. Molchanov draws attention to the need to correctly understand the meaning of the provision on the prohibition for the court in an adversarial form of legal proceedings to perform the functions of the parties, that is, to perform procedural actions in their place. In the author's opinion "this does not mean that the court takes the position of an outside observer regarding the contest of parties in the process" [11].

Indeed, the procedural law contains provisions on the powers of the court to establish circumstances that go beyond those that have been submitted for consideration by the parties. So, according to Part 2 of Article 12 of the Code of Civil Procedure of the Russian Federation, the court not only manages the process, but also creates conditions for the comprehensive and full study of evidence and the establishment of factual circumstances when considering and resolving civil cases. In addition, in some cases, the court, on its own initiative, takes steps to clarify the circumstances of the case: according to Articles 79, 87, and Item 8 of Part 1 of Article 150 of the Code of Civil Procedure the Russian Federation 
the court can appoint examination, according to Part 2 of Article 56 of the Code of Civil Procedure the Russian Federation - to carry out circumstances on which the parties did not refer in the performances, on discussion, etc.

The arbitration proceedings contain similar provisions. So, according to Part 2 of Article 9 of the Arbitration Code of the Russian Federation, the arbitration court creates conditions for the full and complete establishment of factual circumstances during the consideration of the case. In accordance with Part 5 of Article 66 of the Arbitration Code of the Russian Federation, in case of failure of the state authorities, local self-government bodies, other bodies and officials to submit evidence on cases, arising from administrative and other public legal relations, the arbitration court requests evidence from these bodies on its own initiative.

The Code of Administrative Proceedings of the Russian Federation with a view to the correct resolution of administrative cases in Part 1 of Article 63 gives the court the right to seek evidence on its own initiative. The Part 2 of Article 77 of the Code of Administrative Proceedings of the Russian Federation provides for the right of the court, on its own initiative, to appoint an expert examination if it is necessary to verify the application for falsification of the evidence submitted, or in connection with the revealed circumstances of the administrative case and the evidence provided.

One of the elements of establishing truth in a criminal case is the duty of the authorized state bodies and officials to determine the relevant signs of the crime and the inherent characteristics of this composition in each specific case. This duty is not only the professional obligation of judges and investigators, but also a moral one [12]. In this connection, we can agree that "the exercise of its directly regulatory function by law directly depends on the morality of the subjects applying the legal norms. In law enforcement, those ethical principles must be implemented, which the legislator puts into the content of law" [13]. E.V. Bryanskaia notes that "moral principles presuppose the qualification of a crime in accordance with the norms of law, base it on the legality of activity, the literacy of law enforcement officers and the court, and also on their conscience, which is the basis for the formation of their internal conviction" [14].

Along with this, the current version of Article 73 of the Code of Criminal Procedure of the Russian Federation directs the procedural activity of the investigator not only to establishing and proving the guilt of the person (s) brought to criminal responsibility, but also to clarifying the circumstances leading to release from criminal liability and punishment. The implementation of this activity corresponds to the appointment of a criminal proceeding, as defined in Item 2, Part 1, Article 6 of the Code of Criminal Procedure of the Russian Federation and consisting in protecting the person from an unlawful and unfounded charge [15].

On the other hand, according to Item 6 of Part 1 of Article 237 of the Code of Criminal Procedure, the court, including on its own initiative, has the right to return the criminal case to the prosecutor in order to remove obstacles to its consideration in the event that the actual circumstances stated in the indictment testify to the existence of grounds for qualifying the actions of the accused as a more serious crime, or during the preliminary hearing or trial, factual circumstances indicating the existence of grounds for qualifying the actions of these individuals as a more serious crime were established.

Thus, "the definition of the subject of proof in criminal cases in the law serves to complete identification of the picture of the incident, which indicates the purposefulness of achieving the truth in the criminal case; correct qualification of the crime, and therefore, an objective definition of the person's guilt; individualization and justice of punishment" [E.V. Bryanskaia. Predmet dokazyvaniia v kvalifikatsii prestupnogo deiania (The subject of proof in the qualification of a criminal deed) / E.V. Bryanskaia // Sibirskiy yuridicheskiy vestnik (Siberian legal bulletin). - 2016. - № 4. - P. 96]. 
In addition, the procedural codes contain such a basis for the cancellation of a court decision by a higher authority, as the discrepancy between the court's findings in the decision of the first instance court to the circumstances of the case (Item 3, Part 1, Article 330 of the Code of Civil Procedure of the Russian Federation; Item 3, Part 1, Art. 270 of the Code of Arbitration Procedure of the Russian Federation; Item 3, Part 2, Article 310 of the Code of Administrative Procedure of the Russian Federation; and Part 1, Article 389.15 of the Code of Criminal Procedure of the Russian Federation).

Since all the main aspects of truth are reflected in the analyzed normative acts ontological, axiological and praxeological - it is possible to conclude that the court as an enforcement body takes an active position in the judicial process, based on the need to establish the truth in the case. Therefore, the definition of the principle of objective truth into a separate principle is justified. The implementation of the principle in question does not contradict other principles of judicial procedure. On the contrary, their implementation is impossible in full without establishing the facts of the case, which took place in reality.

In our opinion, the principle of objective truth should be the basis of any law enforcement activity. In addition, the law-making function also relies on the principle of objectivity and truth of knowledge used to form the state will. Consequently, the principle of objective truth should be interpreted not only as an inter-sectorial one, but also as a universal principle, which is the basis for building the entire legal system. Only those norms of law that adequately reflect the objective state and public reality, its laws and development tendencies, can become effective, enforceable and effective.

\section{References}

1. E. M. Chudinov, The nature of scientific truth (Moscow, 1977)

2. A. Poincaré, Science and hypothesis (St. Petersburg, 1906)

3. Aristotle, Collected Works in 4 volumes: volume 1 "Metaphysics:" (Thought, Moscow, 1976)

4. G. V. Stelmashuk, V. I. Strelchenko, V. N. Skvortsov et al., Philosophy: textbook for high schools (LGOU, Khimizdat, St. Petersburg, 2001).

5. K. Marx, F. Engels, Composition (2nd ed., vol. 3) (Moscow, 1924)

6. V. Dal, Explanatory dictionary of the living great Russian language (vol. 2) (M. O. Wolf, St. Petersburg,Moscow, 1881)

7. B. I. Lipsky, Practical nature of the truth (Leningrad, 1988) 